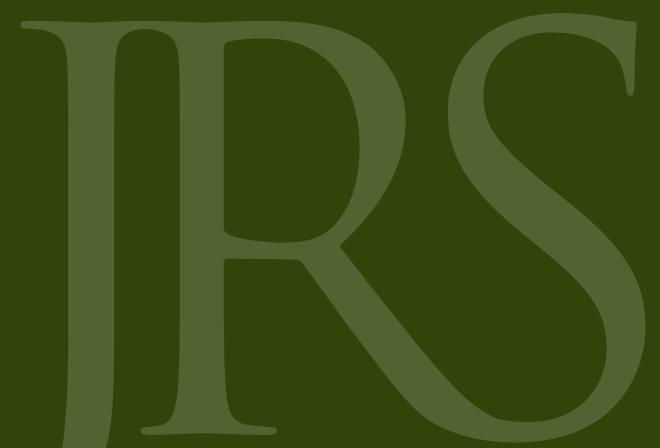

THE JOURNAL OF ROMAN

STUDIES

\author{
VOLUME $100 \mid 2010$
}

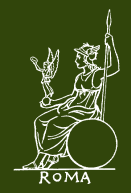


The Society is the leading organisation in the United Kingdom for those interested in the study of Rome and the Roman Empire. Its scope is wide, covering Roman history, archaeology, literature and art down to about A.D. 700. It has a broadly based membership, drawn from thirty-five countries and from all ages and walks of life.

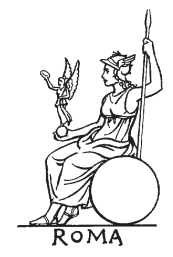

THE SOCIETY FOR THE PROMOTION OF ROMAN STUDIES

\section{THE SOCIETY SUPPORTS}

- an extensive programme of publication:

two annual publications - the Journal of Roman Studies, which contains articles and book reviews dealing with the Roman world in general, and Britannia, which has articles and reviews specifically on Roman Britain

two monograph series - the JRS and Britannia monographs (see back pages)

- a library of around I28,000 volumes, including 660 current periodical titles, maintained jointly with the Hellenic Society and in conjunction with the University of London's Institute of Classical Studies.

It has an international reputation as one of the world's foremost Classics lending libraries. It also houses a lending collection of over 6,700 slides

- summer schools, etc. by the annual award of grants

- archaeology, through grants for excavations, by organising a biennial conference and by providing bursaries to sixth-formers for archaeological fieldwork

- schools, by the award of grants to help the teaching of all aspects of the Roman world

- a programme of public lectures in London, lectures outside London arranged with local branches of the Classical Association, and other occasional events of general interest

Membership is open to all; no entrance fee or professional qualification is required. Members are entitled to:

- receive annually in print form and via online access either the JRS or Britannia or both. Student members receive their journal(s) online only. See back cover

- have access (for an extra fee) to JSTOR's electronic archive of the back volumes of both journals. See back cover

- receive advance notice of forthcoming monographs at special offer prices

- use the library and borrow the Society's books and slides, either in person or by post, while living or resident in the UK

- attend the Society's lectures and other events, of which a programme is circulated in September

- purchase back issues of the journals (see back pages)

Books for review and all correspondence about books must be sent to the Librarian, Hellenic and Roman Societies, Senate House, Malet Street, London wCIE $7 \mathrm{HU}$

\section{MEMBERSHIP RATES}

$\begin{array}{lll} & \text { \& Schools } & * \text { Students } \\ \text { JRS or Britannia } & £_{46 / \mathrm{US} \$ 92} & £_{25} / \mathrm{US} \$ 50 \\ J R S \& \text { Britannia } & £ 69 / \text { US\$ } 338 & £_{45} / \mathrm{US} \$ 90\end{array}$

A discounted rate of $£_{45}$ for one journal and $£ 67$ for both is available to individual members who pay by direct debit.

*Student membership is open to students registered at any institution of higher education in any country.

Life membership is open to individual members of five years' standing aged sixty-five or over, at a cost of $£_{450 / U S \$ 900 .}$

For further details contact:

The Secretary, Roman Society, Senate House, Malet Street,

London WCIE $7 \mathrm{HU}$

Tel.: +44 (0) $20-78628727$

Fax: +44 (o) $20-78628728$

E-mail: office@romansociety.org

Web site: www.romansociety.org

\section{Institutional subscription rates}

The Journal of Roman Studies (ISSN 0075-4358) is published once a year November. The subscription price (excluding VAT) of volume IOO (2010), which includes print and electronic access, is $£_{\mathrm{I}} \mathrm{OO}$ net (US\$200 in the USA, Canada and Mexico) for institutions. EU subscribers (outside the UK) who are not registered for VAT should add VAT at their country's rate.

VAT-registered customers should provide their VAT registration number. Japanese prices for institutions (including ASP delivery) are available from Kinokuniya Company Ltd., P.O. Box 55, Chitose, Tokyo I 56, Japan. Prices include delivery by air where appropriate.

Orders, which must be accompanied by payment, may be sent to a bookseller, subscription agent or direct to the publisher: Cambridge University Press, The Edinburgh Building, Shaftesbury Road, Cambridge CB2 8RU, UK; or in the USA, Canada and Mexico: Cambridge University Press, Journals Fulfillment Department, Ioo Brook Hill Drive, West Nyack, New York I0994-2I33, USA.

(C) The Society for the Promotion of Roman Studies 2010 


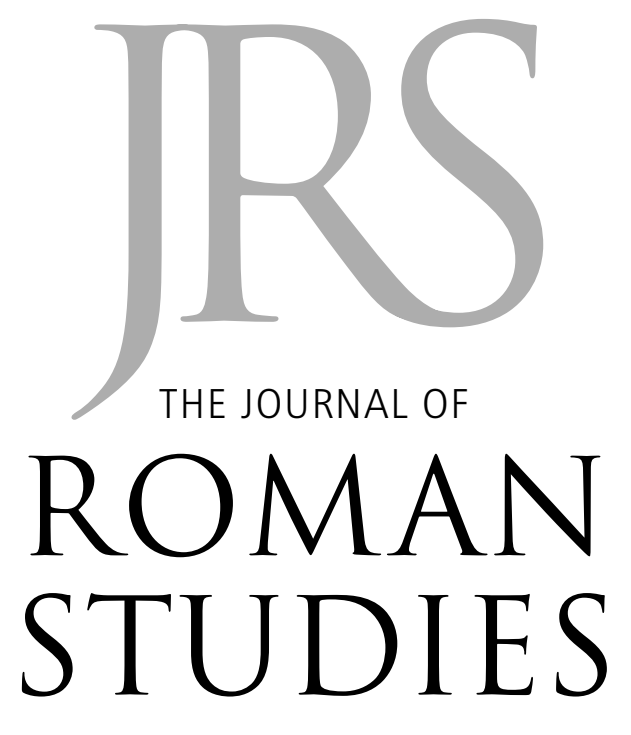

VOLUME $100 \mid 2010$

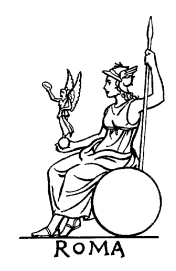

THE SOCIETY FOR THE PROMOTION OF ROMAN STUDIES 
With acknowledgements to

The Cambridge H.A. Thomas Fund

The Institute of Classical Studies

(C) The Society for the Promotion of Roman Studies

ISSN $0075-4358$ (Print)

ISSN I 753-528x (Online)

Typeset by Forewords, Oxford, UK

Printed by Bell \& Bain, Glasgow, UK 


\section{Contents}

xii ARMAND D'ANGOUR, ENGLiSH By COLIn SYDENHAM, Celebratory Verses Presented to the Society for the Promotion of Roman Studies on the Occasion of their Centenary by the Society for the Promotion of Hellenic Studies

\section{ARTICLES}

I Christopher stray, 'Patriots and Professors': A Century of Roman Studies, I9io-20io

32 IRENE PEIRANO, Hellenized Romans and Barbarized Greeks. Reading the End of Dionysius of Halicarnassus, Antiquitates Romanae

PETER HESLIN, Virgil's Georgics and the Dating of Propertius' First Book

69 EMILY GOWERS, Augustus and 'Syracuse'

88 LUKE ROMAN, Martial and the City of Rome

I 8 C. L. WhitTon, Pliny, Epistles 8.I 4: Senate, Slavery and the Agricola

I 40 TRISTAN J. POWER, Pliny, Letters 5.IO and the Literary Career of Suetonius

I63 PETER THONEMANN, The Women of Akmoneia

I79 KEVIN W. WILKINSON, Palladas and the Foundation of Constantinople

I95 DOUglas RYAN boIN, Late Antique Ostia and a Campaign for Pious Tourism: Epitaphs for Bishop Cyriacus and Monica, Mother of Augustine

\section{SURVEY ARTICLE}

JOHN R. PATterson, The City of Rome Revisited: From Mid-Republic to Mid-Empire

\section{REVIEW ARTICLE}

ROBIN OSBORNE AND CAROLINE VOUT, A Revolution in Roman History?

\section{REVIEWS}

(in alphabetical order)

258 ARWEILER, A. H. AND B. M. GAULY (Eds), Machtfragen: zur kulturellen Repräsentation und Konstruktion von Macht in Antike, Mittelalter und Neuzeit (By Ida Östenberg)

353 AUGER, D. AND É. WOLFF (Eds), Culture classique et christianisme: mélanges offerts à Jean Bouffartigue (By Sophie Lunn-Rockliffe)

339 Avanzini, A. (Ed.), A Port in Arabia between Rome and the Indian Ocean (3rd C. BC-5th C. $A D)$. Khor Rori Report 2 (By Heidrun Schenk)

260 BANG, P., The Roman Bazaar: a Comparative Study of Trade and Markets in a Tributary Empire (By Constantina Katsari)

265 BeArd, M., Pompeii: the Life of a Roman Town (By Joanna Paul)

270 BELlandi, F. AND R. FERRI (Eds), Aspetti della scuola nel mondo romano. Atti del convegno (Pisa, 5-6 Dicembre 2006) (By Teresa Morgan)

330 Bellelli, V., F. DelPino, P. MOSCATI AND P. SANTORO, Munera Caeretana. In ricordo di Mauro Cristofani. Atti dell'incontro di studio, Roma (CNR), I Febbraio 2008 (By Michael Crawford) 
273 BONNET, C., S. RIBICHINI AND D. STEUERNAGEL (Eds), Religioni in contatto nel Mediterraneo antico. Modalità di diffusione e processi di interferenza. Atti del 3 colloquio "Le Religioni Orientali nel Mondo Greco e Romano” (By Michael Crawford)

347 BOWEs, K., Private Worship, Public Values, and Religious Change in Late Antiquity (By Lisa Alberici)

248 BRADLEY, G. AND J.-P. WILSON (Eds), Greek and Roman Colonization. Origins, Ideologies and Interaction (By S. J. Northwood)

302 BRAUnd, s., Seneca, De Clementia (By Jula Wildberger)

257 CADiOU, F., Hibera in terra miles: Les Armées romaines et la conquête de l'Hispanie sous la République (2 I8-45 Av. J.C.) (By John Richardson)

328 CAPRIOLI, F., Vesta aeterna: l'Aedes Vestae e la sua decorazione architettonica (By John Stamper)

3 I 4 CARUSO, C. AND A. LAIRD (Eds), Italy and the Classical Tradition. Language, Thought and Poetry I300-I600 (By L. B. T. Houghton)

27 I CIMA, M. AND E. TAlamo, Gli Horti di Roma antica (By Annette Giesecke)

329 CiUrletti, G. (Ed.), Fra il Garda e le Alpi di Ledro. Monte S. Martino. Il luogo di culto (ricerche e scavi I969-I979) (By Neil Christie)

297 ClaAsSEn, J.-M., Ovid Revisited: the Poet in Exile (By Samuel Huskey)

254 Clark, A., Divine Qualities: Cult and Community in Republican Rome (By Fay Glinister)

284 CLAUSEN, M., Maxima in sensibus veritas? Die platonischen und stoischen Grundlagen der Erkenntniskritik in Ciceros Lucullus (By Myrto Hatzimichali)

300 COFFEE, N., The Commerce of War: Exchange and Social Order in Latin Epic (By Jonathan Mannering)

346 COOPER, K., The Fall of the Roman Household (By Claire Sotinel)

323 DAEHner, J. (Ed.), The Herculaneum Women. History, Context, Identities (By Shelley Hales)

335 DE CAZAnove, o., Civita di Tricarico. I. Quartier de la Maison du Monolithe et l'enceinte intermédiaire (By Penelope Goodman)

348 De Gaetano, M., Scuola e potere in Draconzio (By Chiara O. Tommasi Moreschini)

246 DE LIGT, L. AND S. NORTHWOOD (Eds), People, Land and Politics: Demographic

Developments and the Transformation of Roman Italy 300 BC-AD I4 (By Marta García Morcillo)

276 DE VAAN, M., Etymological Dictionary of Latin and the Other Italic Languages (By Hilla Halla-aho)

333 DEMma, F., Monumenti pubblici di Puteoli. Per'un archeologia dell'architettura (By Matthew Nicholls)

349 DUNN, G., Tertullian's Adversus Iudaeos: a Rhetorical Analysis (By Jaclyn Maxwell)

280 DuTsch, D., Feminine Discourse in Roman Comedy: on Echoes and Voices (By Kristina Milnor)

305 FAIN, G., Writing Epigrams: the Art of Composition in Catullus, Callimachus and Martial (By Bob Cowan)

25 I FARNEY, G., Ethnic Identity and Aristocratic Competition in Republican Rome (By Kathryn Lomas)

320 FEJFer, J., Roman Portraits in Context (By Jeremy Tanner)

3 I 3 FRANGOULIDIS, S., Witches, Isis and Narrative: Approaches to Magic in Apuleius' Metamorphoses (By Sarit Stern) 
Fratantuono, L., A Commentary on Virgil, Aeneid XI (By Anne Rogerson) FRISCHER, B., J. CRAWFORD AND M. DE SIMONE, The Horace's Villa Project, I997-2003 (By Mantha Zarmakoupi)

GALL, D. AND A. WOLKENHAUER (Eds), Laokoon in Literatur und Kunst: Schriften des Symposions 'Laokoon in Literatur und Kunst' vom 30.I I.2006, Universität Bonn (By Katharina Lorenz)

garani, M., Empedocles Redivivvs: Poetry and Analogy in Lucretius (By Daniel Marković) GARDNER, G. AND K. OSTERLOH (Eds), Antiquity in Antiquity: Jewish and Christian Pasts in the Greco-Roman World (By Jodi Magness)

GARDNer, I., S. LIEU AND K. PARRY (Eds), From Palmyra to Zayton: Epigraphy and Iconography (By Ted Kaizer)

GUIDO, L., Romania vs Barbaria: Aspekte der Romanisierung Sardiniens (By Peter van Dommelen)

GUNDerson, E., Nox Philologiae: Aulus Gellius and the Fantasy of the Roman Library (By Shane Butler)

GÜNTHER, s., 'Vectigalia nervos esse rei publicae'. Die indirekten Steuern in der römischen Kaiserzeit von Augustus bis Diokletian (By Kristian Mohr Mersing)

GUZZO, P. AND M.-P. GUIDOBALDI (Eds), Nuove ricerche archeologiche nell'area Vesuviana (scavi 2003-2006): atti del convegno internazionale, Roma, I-3 Febbraio 2007 (By Virginia L. Campbell)

Hall, J., Politeness and Politics in Cicero's Letters (By Sandra Citroni Marchetti) HARDIE, P. (Ed.), Paradox and the Marvellous in Augustan Literature and Culture (By Laura Jansen)

HEINEN, H. (Ed.), Menschenraub, Menschenhandel und Sklaverei in Antiker und moderner Perspektive (By Ulrike Roth)

HIRSCH-LUIPOLD, R., H. GÖRGEMANNS AND M. VON ALBRECHT (Eds), Religiöse Philosophie und philosophische Religion der frühen Kaiserzeit: Literaturgeschichtliche Perspektiven (By Lee M. Jefferson)

HOPE, v., Roman Death: Dying and the Dead in Ancient Rome (By Emma-Jayne Graham) HORSFAll, N. (Ed.), Virgil, Aeneid 2: a Commentary (By Ruth Parkes)

HOWELL, P., Martial (By Ilaria Marchesi)

HÜBNER, S. AND D. RATZAN (Eds), Growing up Fatherless in Antiquity (By Christina A. Clark) HUmbert, M., Le Dodici Tavole. Dai decemviri agli umanisti (By Michael Crawford) JOHNE, K.-P. IN ASSOCIATION WITH U. HARTMANN AND T. GERHARDT (Eds), Die Zeit der Soldatenkaiser (By John F. Drinkwater)

JOHnson, w. R., A Latin Lover in Ancient Rome: Readings in Propertius and his Genre (By Teresa Ramsby)

KeITH, A., Propertius: Poet of Love and Leisure (By Peter Heslin)

KELlY, C., Attila the Hun, Barbarian Terror and the Fall of the Roman Empire (By Michael Whitby)

KEULEN, w., Apuleius Madaurensis Metamorphoses: Book I - Text, Introduction and Commentary (By Paula James)

KeUlen, w., Gellius the Satirist: Roman Cultural Authority in the Attic Nights (By Vera Binder)

KOUSSER, R. M., Hellenistic and Roman Ideal Sculpture: the Allure of the Classical (By 
Michael Squire)

278 KROPP, A., Magische Sprachverwendung in vulgärlateinischen Fluchtafeln (Defixiones) (By Gian Franco Chiai)

345 LEE, A., War in Late Antiquity: a Social History (By Richard Alston)

3 I7 LIANERI, A. AND V. ZAJKO (Eds), Translation and the Classic: Identity as Change in the History of Culture (By Ian Ruffell)

3 I 5 LOWE, D. AND K. SHAHABUDIN (Eds), Classics for All: Reworking Antiquity in Mass Culture (By Alison Futrell)

288 MARKović, D., The Rhetoric of Explanation in Lucretius' De Rerum Natura (By Gordon Campbell)

266 Mastino, A., Storia della Sardegna antica (By Peter van Dommelen)

298 MCgowan, M., Ovid in Exile: Power and Poetic Redress in the Tristia and Epistulae ex Ponto (By John Geyssen)

327 MENEGHINI, R. AND R. SANTANGELI VALENZANI, I Fori imperiali: gli scavi del comune di Roma (I99I-2007) (By Michael Anderson)

3I9 NEWBy, Z. AND R. LEADER-NEWBy (Eds), Art and Inscriptions in the Ancient World (By Benet Salway)

336 NOGALES, T. AND J. GONZÁlEZ (Eds), Culto imperial: política y poder (By Leonard A. Curchin)

285 Novoкнатко, A., The Invectives of Sallust and Cicero: Critical Edition with Introduction, Translation, and Commentary (By John T. Ramsey)

264 REVELL, L., Roman Imperialism and Local Identities (By Edward Herring)

306 RIMELL, V., Martial's Rome: Empire and the Ideology of Epigram (By Luke Roman)

354 ROUSSEAU, P. AND M. PAPOUTSAKIS, Transformations of Late Antiquity: Essays for Peter Brown (By Richard Flower)

250 SACCHI, O., Regime della terra e imposizione fondiaria nell'età dei Gracchi: testo e commento storico-giuridico della Legge Agraria del I I I A.C. (By Michael Crawford)

256 SANTALUCIA, B. (Ed.), La Repressione criminale nella Roma repubblicana fra norma e persuasione (By O. F. Robinson)

289 SAUNDERS, T., Bucolic Ecology. Virgil's Eclogues and the Environmental Literary Tradition (By John Henderson)

325 SCHEID, J. (Ed.), Pour une archéologie du rite. Nouvelles perspectives de l'archéologie funéraire (By Maureen Carroll)

303 SMOlenaArs, J., H.-J. VAN DAM AND R. NAUTA (Eds), The Poetry of Statius (By Randall Ganiban)

28 I STEVenson, T. AND M. WILSON (Eds), Cicero's Philippics: History, Rhetoric and Ideology (By Gabor Tahin)

259 TAKÁCs, s., The Construction of Authority in Ancient Rome and Byzantium: the Rhetoric of Empire (By Hannah Swithinbank)

253 TATum, w. J., Always I Am Caesar (By Federico Santangelo)

338 TOMBER, R., Indo-Roman Trade: from Pots to Pepper (By K. Winther-Jacobsen)

277 TRIANTAFILLIS, E., Le Iscrizioni italiche dal 1979 (By Michael Crawford)

28 I USHER, S., Cicero's Speeches: the Critic in Action (By Kathryn Tempest)

272 VAN ANDRINGA, W. (Ed.), Sacrifices, marché de la viande et pratiques alimentaires dans les 
cités du monde romain = Meat: Sacrifice, Trade and Food Preparation in the Roman Empire (By Michael Beer)

337 VEYRAC, A., Nîmes romaine et l'eau (By Simon Esmonde Cleary)

296 VOLK, K., Manilius and his Intellectual Background (By Charles McNelis)

334 VOlPE, G., M. STRAZZULLA AND D. LEONE (Eds), Storia e archeologia della Daunia in ricordo di Marina Mazzei (By Michael Crawford)

350 Williams, M., Authorised Lives in Early Christian Biography. Between Eusebius and Augustine (By Lieve van Hoof)

279 WINSBURY, R., The Roman Book (By Joseph Howley)

25 I Wiseman, T. P., Remembering the Roman People: Essays on Late-Republican Politics and Literature (By Harriet Flower)

356 Proceedings of the Society 


\section{THE JOURNAL OF ROMAN STUDIES}

\section{Policy Statement}

SCOPE: The Journal aims to publish papers in the full range of the field which the Roman Society was established to promote, that is 'the study of the history, archaeology, literature, and art of Italy and the Roman Empire, from the earliest times down to about A.D. 700'. Although the emphasis of the Journal has been on historical themes, we welcome submissions on literary, archaeological and art historical topics, including those on issues of cultural and intellectual history that cut across these categories. Papers primarily concerned with the archaeology of Roman Britain should be sent in the first place to Britannia; those concerned with the archaeology of the Roman Empire at large are equally welcomed by this Journal.

STYLE: The Journal seeks to publish papers that make a fresh and significant contribution to the understanding of the Roman world, and have the potential to stimulate further discussion. Though papers have in recent years tended to be lengthy, the Journal is also keen to publish shorter articles so long as they address issues of general importance. All papers should be carefully thought through and clearly argued; this does not necessarily involve a heavy use of footnotes, but does involve clear statement of the argument and of its broader significance, and adequate signposting to the reader of the steps in the argument. They should so far as possible be accessible to the non-specialist reader, and citations in ancient languages should always be translated.

Editorial procedure: The Journal is run by an Editorial Committee: Professor G. D. Woolf (Editor), Professor C. E. W. Steel (Review Editor), Professor M. Beard, Professor E. G. Clark, Professor C. H. Edwards, Professor P. R. Hardie, Mr H. R. Hurst, Dr C. Kelly, Professor A. R. Sharrock and Dr P. Thonemann. Submissions are circulated at the Editor's discretion to members of the Committee and, where appropriate, to other specialist readers. In order to ensure maximum impartiality, all submissions are circulated without indication of authorship; it is helpful if submissions do not carry the author's name, institutional affiliation or other indications of identity. The process of refereeing necessarily takes time, but authors may expect to receive a verdict within three months of submission. Detailed comments are normally sent only to authors of submissions which have been accepted, or which are thought suitable for resubmission. Authors are frequently invited to revise submissions in the light of such comments.

Submission: Electronic submission by e-mail to the Editor is preferred. All submissions should be accompanied by a separate statement of the name, title, affiliation and postal address of the author: none of these should appear on the submission itself. Documents may be submitted in Word or as PDFs. On occasion the Editor may request a hard copy and/or submission on CD-ROM if fonts or illustrations make this desirable. Further instructions will be issued to the authors of accepted articles regarding what is needed for the final version. The Journal is scheduled to appear in November each year. The optimum time for submission is between April and December of any given year for appearance in the following year's issue.

STYLE GUIDELINES: Detailed guidelines on matters of presentation are available on the Society's website http://www.romansociety.org, but recent issues of the Journal should be treated as a general guide.

Electronic matters: The Society's website (www.romansociety.org) gives the table of contents and abstracts of all articles in the Journal. Recent issues of the Journal and Britannia can be accessed online at www.journals.cambridge.org. The Society permits JSTOR (a system of electronic archiving) to put on its website back issues of the Journal (for more information see www.romansociety.org).

Article submissions and all general enquiries should be addressed to the Editor, Professor G. D. Woolf (gdw2@st-andrews.ac.uk), School of Classics, University of St Andrews, St Andrews, Fife KYi 6 9AL, UK.

Correspondence relating to reviews should be addressed to the Review Editor, Professor C. E. W. Steel (c.steel@classics.arts.gla.ac.uk), Library of the Hellenic and Roman Societies, Senate House, Malet Street, London WCiE $7 \mathrm{HU}$, UK.

Books for review should be sent to the Librarian, Hellenic and Roman Societies, Senate House, Malet Street, London WCIE $7 \mathrm{HU}, \mathrm{UK}$. 


\section{Roman Society Journals: The Future}

Members of the Society will be gradually becoming aware of a number of changes in the way its journals, Journal of Roman Studies and Britannia, are produced and disseminated. One tell-tale sign is the appearance on the 2010 volume of each journal of the logo of Cambridge University Press accompanying the more familiar Roma of the Society. This is a sign that in its centenary year, after one hundred years of publishing its journal(s) in house, the Society has decided to confide the publishing side of its activities to a leading academic and commercial publishing house. In this note I would like to offer members an account of the rationale behind this decision and to outline what the move will mean both now and for the future.

The principal reason for the move is that CUP, in particular its Journals division, offers far greater resources of technical and marketing expertise than the Society could ever hope to command on the basis of its own resources. In particular, CUP has the resources and experience to transfer the principal medium of publication for the journals from traditional print volumes to digital dissemination. However comforting the sight of a run of the printed journals on the shelves, it is a fact that both libraries and other institutional subscribers, as well as individual users, have increasingly moved to making journals available and to accessing them online. For libraries the savings in shelving are considerable and for the individual the journals become accessible from wherever they can get online, and of course the relevant volume is never 'out'. Indeed, the Society had already moved a long way down this route with electronic access to current and recent volumes through Ingenta and access to back numbers through JSTOR. So in a way this is simply the working-through of the final stages of this journey. But there is more to it than that, since the resources of CUP allow much greater and more sophisticated use of electronic formats, as outlined below. As a major academic publisher with offices world-wide, CUP affords the Society the prospect of raising the visibility of the journals and increasing their penetration into academic markets where at present they have little saliency. In part this is simply by information on the journals being placed on the CUP websites, but more importantly it is through their marketing division actively promoting the journals in new markets or existing markets where there seems still to be room for further take-up of the journals. Allied to this there is what might be termed a defensive reason for the move. CUP offers institutions such as universities both in Europe and in North America 'bundles' of journals in related fields (and several other British academic classical and archaeological journals have also recently signed up with the Press). This means that subscribing institutions cannot pick off individual journals in the bundle; in a time of severe constraints on academic and library spending this would have been a serious risk for the Society's journals had they not had the protection of the herd. It should also be added that the agreement that the Society has entered into with CUP is one that should have a very favourable financial out-turn for the Society, attracting substantially more revenue than the Society would have been able to raise through its own unaided efforts.

So how will this impact on the production and dissemination of the journals, and how will this affect the experience of institutional and individual subscribers? The first thing to emphasise is that academic control of the journals and their content remains with the Society. It will be the editors of the two journals, their editorial sub-committees and the Editorial Committee of the Society that will remain responsible for the receipt, refereeing, acceptance or rejection of papers and such matters as commissioning reviews or other contributions and for other elements such as 'Roman Britain in 20xx', as well as any wider decisions about the form and content of the journals. Thus the journals will remain as much the public intellectual property and vehicle of the Society as ever they have been over the last century. Once an article or other material has been accepted and finalised, the first difference subscribers will notice will be that it will become available through the 
'Firstview' facility of the CUP website, which is when it will receive a DOI (Digital Object Identifier) and thus be 'published'. This will minimise publication delays (which can be crucial in the world of deadlines such as that for the Research Excellence Framework in the UK) and will also enable more rapid access to significant new discoveries, particularly perhaps the archaeological. The complete, paginated journals will continue to be published (in print and online) in the autumn, at which time the Firstview version will be taken down. Subscribing institutions and members (with the exception of student members who already receive online only) will in future receive the journal in both print and electronic form. The digital format will also of its nature allow immediate and future technical improvements in the journals such as images in colour as well as black-andwhite, and in due course advances such as embedded Java applets with manipulable $3-\mathrm{D}$ images of papyri, inscriptions, structures, objects allowing far more detailed autopsy by the reader. There can also be links through to data-bases of a size that would simply not be publishable in the journals by conventional means, or to related sites or other resources. More immediate changes are in the appearance of the volumes, in particular the alterations to the covers of both journals and the introduction of a photograph for the front cover of Britannia. This is also the last year in which Britannia will have an index, since in future the digital format will make it easier to locate the desired information through a search.

On a related topic, the Society's monograph series. Since these are not journals as such they did not form part of the agreement with CUP. The JRS and Britannia sub-committees took the opportunity of the negotiations with CUP to review their activity in this area, and the JRS sub-committee recommended to the Editorial Committee and thus to Council that the JRS monograph series be terminated with the publication of the forthcoming volume of Monumenta Asiae Minoris Antiqua, and this was agreed. The Britannia sub-committee took the view that there was still a place for its monograph series, which has always operated under rather different financial circumstances, accordingly the Britannia monograph series will continue in being.

I would also like to note that the move to publication with CUP is already being greatly helped by the agreement of Dr Lynn Pitts to remain as Publications Secretary: the negotiation of the agreement with CUP on what was agreed by Council to be terms very favourable to the Society was greatly helped by both Dr Pitts and the Secretary, Dr Fiona Haarer, to both of whom we are greatly indebted.

In sum, subscribers to the journals, be they institutions or individuals, should notice relatively little change to the established pattern of publication of the journals. Over the next few years it is hoped they will see an improvement as more digital resources come online in the journals. It was the purpose of the Council of the Roman Society by this link-up with CUP not only to safeguard the continued existence of the journals that over the last hundred years have been such a major contribution by the Society to the world of scholarship but also that as the second century of their publication dawns they should continue to improve in the content, format and services offered to subscribers and other readers across a global and digital academic world scarcely to be imagined by the Society's founders.

Simon Esmonde Cleary Chairman, Editorial Committee 


\title{
SOCIETY FOR THE PROMOTION OF ROMAN STUDIES
}

Company reg. no. I I 4442 Charity reg. no. 2 I0644

\section{Officers and Council 2010-I I}

\author{
President \\ Dr Andrew Burnett, FBA, FSA \\ Vice-Presidents \\ Professor Alan K. Bowman, FBA, FSA Professor Michael G. Fulford, FBA, FSA \\ Rev. Professor John S. Richardson, FRSE
}

Elected June 2008

Professor Barbara E. Borg

Dr William A. R. Bowden

Dr Alison E. Cooley

Dr Steven J. Green

Dr Lucy H. C. Grig

Dr Matthew C. Nicholls

Ms Sally A. Worrell, FSA

\author{
Elected Members of Council \\ Elected June 2009 \\ Professor W. Mary Beard, FBA, FSA \\ Dr Anna J. Clark \\ Professor Catharine H. Edwards \\ Dr Rebecca E. Flemming \\ Dr Ted Kaizer \\ Dr Philip B. Kay \\ Dr Jonathan R. W. Prag \\ Professor Eberhard W. Sauer, FSA
}

\author{
Elected June 2010 \\ $\mathrm{Mr}$ Stephen R. Clews \\ Dr Emily J. Gowers \\ Dr Claire Holleran \\ Dr Genevieve Liveley \\ Dr Gesine Manuwald \\ Dr Neil B. McLynn \\ Mr David A. Stuttard \\ Dr Rebecca J. Sweetman, FSA
}

Hon. Treasurer: Dr Philip B. Kay

Hon. Secretary: Mr T. Sam N. Moorhead, FSA
Secretary: Dr Fiona K. Haarer, FSA

Auditors: Larkings

\section{Honorary Vice-Presidents}

Mr Colin H. Annis, MA, ALA

Professor Dame Averil Cameron, CBE, FBA, FSA

Professor Michael H. Crawford, FBA

Professor Sheppard S. Frere, CBE, FBA

Professor Atsuko Gotoh

Professor Edward J. Kenney, FBA

Mr Graham E.A. Kentfield

Mr J. H. Colin Leach

Dr Barbara M. Levick, FSA
Mrs Elaine Matthews, FSA

Professor Sir Fergus G. B. Millar, FBA, FSA

Professor Robin G. M. Nisbet, FBA

Dr Simon R. F. Price

Dr Joyce M. Reynolds, FBA, FSA

Professor Malcolm Todd, FSA

Professor Andrew F. Wallace-Hadrill, OBE, FSA

Professor John J. Wilkes, FBA, FSA

Professor T. Peter Wiseman, FBA, FSA
Professor E. Badian

Professor A. Carandini

Professor K. M. Coleman

Professor E. Gabba

Professor A. T. Grafton

Professor E. S. Gruen
Honorary Members of the Society

Professor M. Mayer

Professor C. Nicolet

Professor Dr D. Nörr

Professor S. Panciera

Professor H. von Petrikovits

Professor P. Zanker

Hon. American Secretary: Professor Glen W. Bowersock

Hon. Librarian: Professor Michael H. Crawford

Librarian: Mr Colin H. Annis

Publications Secretary: Dr Lynn F. Pitts, FSA
Chairman of Schools Committee: Mr Steven C. Hunt Chairman of Archaeology Committee: Dr Peter Guest, FSA

Editorial Committee

Chairman: Dr A. Simon Esmonde Cleary, FSA

\section{Journal of Roman Studies}

Editor: Professor Gregory D. Woolf, FSAScot.

Review Editor: Professor Catherine E. W. Steel

Professor W. Mary Beard, FBA, FSA

Professor E. Gillian Clark

Professor Catharine H. Edwards

Professor Philip R. Hardie, FBA

Professor Henry R. Hurst, FSA

Dr Christopher Kelly

Professor Alison R. Sharrock

Dr Peter Thonemann

\section{Britannia}

Editor: Mr Richard J. Brewer, FSA

Review Editor: Professor Barry C. Burnham, FSA

Mr Paul Booth, FSA

Dr Hilary E. M. Cool, FSA

Dr Hella Eckardt, FSA

Professor Michael G. Fulford, FBA, FSA

Dr Fraser Hunter, FSA

Dr John Peter Wild, FSA (Editor, Britannia Monographs)

Contributions to the JRS should be sent to Professor G. D. Woolf, The Editor,

Journal of Roman Studies, School of Classics, University of St Andrews, St Andrews, Fife KY I 6 9AL

Contributions to Britannia should be sent to Mr R. J. Brewer, The Editor, Britannia,

Department of Archaeology \& Numismatics, National Museum of Wales, Cathays Park, Cardiff CFI 3 NP.

Books for review for both the JRS and Britannia must be sent to The Librarian, Joint Library,

Hellenic and Roman Societies, Senate House, Malet Street, London wCIE 7HU

(C) Society for the Promotion of Roman Studies 2010. All rights reserved. 


\section{Celebratory Verses Presented to the Society for the Promotion of Roman Studies on the Occasion of their Centenary by the Society for the Promotion of Hellenic Studies}

COMPOSED BY ARMAND D'ANGOUR, ENGLISH BY COLIN SYDENHAM

Arma si magni celebras Maronis, nec minus nugas lepidas Catulli, seu tibi carmen placet expolitum vatis Horati,

si parum cauti recitas Petroni fabulas, cenamque Trimalchionis, sive quos acres Juvenalis atrox iactat iambos,

Livius si quos Tacitusve mordax fingit annales Italos recordans, Tullii seu tu petis eloquentis discere dicta,

sculpta seu priscae monumenta Romae pertinax quaeris tabulasque pictas, sive rimaris foliis refertam bibliothecam,

huc veni, lector, studiis Latinis maxime aut forsan modice peritus: ecce, Romanos licet hic abunde visere libros;

pande thesaurum, veterisque turbae conscius gaude socius vocari, quae per aetatem deciens bilustrem munera tendit.

Sapphicis olim numeris renatum saeculum Romae cecinit poeta, Helladis sic vos Socii renatos concelebramus.
If Virgil's epic, or Catullus's

seductive pleasantries are what you praise, or Horace's exquisite skill to craft the jewelled phrase;

if brash Petronius and Trimalchio's epicurean orgy suit your taste, or the indignant barbs of Juvenal with poison laced;

or if to Livy or sharp Tacitus in search of Roman history you go, or for the arts of eloquence you turn to Cicero;

if sculpted monuments from Roman times and frescoed villa-walls attract your gaze; if bookishly you scour the library's well-furnished bays;

come hither, reader, of whatever grade, expertly or more moderately skilled, by Roman texts in plenty here your needs shall be fulfilled;

unveil the treasure, and rejoice to be a member of a long-respected band, whose life of service now a hundred years has proudly spanned.

To greet renewed Roman society a Sapphic song was once the poet's choice: To your renewal we Hellenic friends now raise our voice. 